\title{
УПЛИВ АНГЛОМОВНИХ ЗАПОЗИЧЕНЬ НА ЛЕКСИЧНИЙ СКЛАД ТЕКСТІВ ПУБЛІЦИСТИЧНОГО СТИЛЮ
}

Майструк Т. С. Уплив англомовних запозичень на лексичний склад текстів публіцистичного стилю.

У статті аналізується основне призначення англійських запозичень у публіцистичних текстах. Незважаючи на деякі позитивні сторони, шкідливість англізмів виявляється у їх надмірному або недоречному використанні, що може супроводжуватися витісненням питомої лексики. Найкраще цей процес простежується в текстах публіцистичного стилю.

Ключові слова: англійські запозичення, позитивний вплив, шкідливість, публіцистичний стиль.

Майструк Т.С. Влияние английских заимствований на лексический состав текстов публицистического стиля.

В статье анализируется основное предназначение английских заимствований в публицистических текстах. Несмотря на некоторые позитивные стороны, вредное влияние англизмов выражается в их чрезмерном или неуместном использовании, что может сопровождаться вытеснением украинской лексики. Наиболее хорошо этот процесс видим в текстах публицистического стиля.

Ключевые слова: английские заимствования, позитивное влияние, вредное влияние, публицистические тексты.

Maystruk T. S. The influence of English borrowings on the lexical vocabulary of the publicistic texts.

The article presents the main assignment of English borrowings for lexical system of publicistic texts. In spite of some positive sides the harmfulness of English borrowings is presented in their excessive or inappropriate using which can be followed by displacement of Ukrainian vocabulary. This process is better seen in the publicistic texts.

Key words: English borrowings, positive influence, negative influence, publicistic texts.

У зв’язку 3 сучасною тенденцією до англізації важливим $\epsilon$ дослідження функціонального призначення англійських запозичень, адже надмірна їх кількість, а також безпідставне вживання можуть становити загрозу для української мови.

Останнім часом питання впливу англізмів на лексичний склад мовиреципієнта стало дискусійним, думки дослідників у зв’язку з цим є досить розбіжними. Одні мовознавці (Т. Лещук, І. Каминін, О. Мисечко, Д. Щерба, Є. Карпіловська) знаходять лише позитивні сторони англійських запозичень, інші (В. Пілецький, В. Радчук, І. Фаріон, Л. Архипенко, Л. Полюга, О. Палій, О. Пономарів, П. Селігей, Ю. Карпенко) - виокремлюють негативні аспекти присутності англомовної лексики в українській мові.

Метою нашої статті є визначення особливостей функціонування та впливу англомовних одиниць на лексичний склад тестів публіцистичного стилю. 
Орієнтація на конкретні тексти, а саме публіцистичні, видається досить актуальною, оскільки англійські лексичні одиниці потрапляють спочатку в тексти, потім через них - у лексичну систему української мови й функціонують уже як абстрактні одиниці. До того ж саме в публіцистичному стилі вживання англізмів зумовлене функціональним призначенням текстів, яке полягає в тому, щоб активно впливати на адресата, модифікувати його свідомість, пропагувати прогресивні ідеї серед широких мас населення [8, с. 140]. На думку Г. Дружина, у сучасній публіцистиці, окрім прагматично загостреної установки на читача, його смаки і пристрасті, розрахунку на його розуміння, виявлено високий ступінь зв'язку семантики й прагматики, що має безпосереднє відношення до проблеми освоєння суспільством запозичення [2, с. 10].

Зважаючи на основні ознаки публіцистичного стилю, а саме: спрямованість на новизну, логізацію та емоційну виразність, оцінку, пристрасне ставлення до предмета мовлення, поєднання точності висловленої інформації, наукових положень із емоційно-експресивною образністю конкретно-чуттєвого бачення питання чи проблеми [3, с. 272], правомірним видається вживання в текстових зразках як стилістично забарвлених, так і стилістично нейтральних англізмів. В останній ситуації такі англомовні запозичення виконують лише номінативну функцію.

Одним із позитивних виявів англомовної присутності в публіцистичних текстах $€$ те, що англізми виступають як необхідні одиниці номінації понять, заповнюючи при цьому лакуни в мові-реципієнті, або сприяють заміні питомих зворотів короткими інтернаціональними термінами. Цей процес можна простежити на основі функціонування англійських запозичень семантичних груп «Суспільство» (біхевіоризм, скамер, селфмейд, буккросинг, секс-апіл, герлскаут, бойскаут, брейншторм) та «Культура» (бодісингер, кекуок, регтайм, спірічуелс, мейнстрім, daпсе-культура, шоу-мен).

Слід зазначити, що вплив англізмів відбувається не лише на лексичному рівні. Він виявляється i в різних семантичних та психологічних модифікаціях. Запозичення іншомовної лексики автоматично призводить до нашарування культур, інтерференції свідомостей двох неспоріднених народів. У результаті неточного, часто хибного розуміння англізми в мові-реципієнті отримують різну інтерпретацію або пояснювального (словники), або контекстуального характеру. Наслідками зміни може бути звуження (спеціалізація) предметно-поняттєвого співвіднесення слова, розширення (генералізація) та зміщення значення - переосмислення лексеми, набуття переносного значення [7, с. 207].

Наведемо кілька прикладів: 1. Цю мету підтримує кожен громадянин держави, якщо одержить чіткий план та щоденні практичні переконання в тому, що це не блеф і ие є результатом і його особистої національної 
позиції (Українське слово, № 42, 15-21.10.08); 2. ...Сорокарічний закарпатець Іван Куриляк - справжній чеський селфмейд (людина, яка зробила себе сама. - авт.), втілення найпотаємнімої заробітчанської мрії.. Але головне - погляд людини, яка не боїться, що перша ж зустріч із місиевою поліиією закінчиться штампом про депортацію (Україна молода, № 49, 18.03.09); 3. I чомусь після кастингів, на яких одні моделі в «обойму» потрапили, а інші - ні, про дискримінаиію немає й мови (Україна молода, № 172, 20.09.06). Англізм блеф [англ. bluff] у мові-етимоні тлумачиться як: 1) надзвичайно стрімкий берег чи схил; 2) спроба обдурити [6, с. 181]. В українській мові пряме його значення - вигадка, обдурювання для того, щоб залякати, удатися до похваляння, перебільшити свою роль у чомусь [4, с. 111]. Однак, крім прямого, в українських словниках фіксуємо ще й переносне значення - прийом у грі в покер, спосіб напустити оману на учасників гри: гравець 3 поганими картами вдає, що в нього є шанс виграти [4, с. 111]. У переносному значенні цей англізм міг би вживатися лише в текстах, пов'язаних із азартними іграми, а в переносному може використовуватися в будь-якій сфері, зокрема і в суспільній. Він позначає відповідне поняття, уносячи додатковий відтінок у значення питомого слова.

У другому прикладі фіксуємо англійське запозичення селфмейд, складене із двох лексем (self - сам, made - зроблений). Воно відсутнє в словниках іншомовних слів, оскільки $є$ авторським неологізмом, пояснюваним у тексті - «людина, яка зробила себе сама». Слід зазначити, що в українській мові значення цього англізму узагальнилося, адже в мові етимоні він тлумачиться як багатство та успіх, яких досягла людина за допомогою власних зусиль та праці, а не за рахунок родинних грошей [6, c. 1538].

Англізм кастинг, представлений третьою ілюстрацією, $\epsilon$ багатозначним: 1) вид змагань рибалок, що полягає в мистецтві володіння риболовними снастями, переважно 3 точності та дальності закидання блешні; 2) попередній відбір учасниць для конкурсу краси чи на роль моделей, манекенниць; 3) визначення складу виконавців, відбір та підбір акторів, часто на конкурсній основі [1, с. 280]. Цілком імовірно, його перше значення архаїзувалося, адже цей англізм фіксуємо здебільшого у двох останніх значеннях. У проілюстрованому прикладі лексема кастинг уживається з другим значенням, називає вже наявне поняття, служить для заміни питомого звороту.

Слід зауважити, що корисними в публіцистичних текстах є не лише ті англомовні запозичення, що називають нові поняття, а й ті, що мають питомі відповідники. Наприклад: Це позначається лише на можливому порядковому номері иих стрічок в ієрархії кінематографічних иінностей... Але не напасешся ж на вас щороку шедеврів. Де ж їх узяти серед загального мейнстріму? Тож втішайтеся тим, щзо $\epsilon$ (Дзеркало тижня, 
№ 5, 14-20.03.09). Англізм мейнстрім (від англ. main - головний та stream течія, напрямок) у мові-етимоні тлумачиться як спосіб життя чи сукупність переконань, що визнаються більшістю людей [6, с. 1117]. В українській мові відбулася спеціалізація значення цієї лексеми: основний напрямок у мистецтві в певний період у літературі, музиці) [1, с. 361]. Поява цього англізму зумовлюється тим, що він служить для заміни питомого виразу однією лексемою.

Позитивним виявом використання англійської лексики в текстах публіцистичного стилю $є$ необхідність створення стилістичного ефекту задля активного впливу на адресата. Так, англізми можуть уживатися в переносному значенні й служити при цьому засобом створення образності, контрасту, іронії, виступати синонімами до питомих лексем, справляючи враження більш високих, урочистих, вишуканих слів, порівняно 3 українськими. У такому разі вони виконують ряд стилістичних функцій: експресивну, оцінну, емоційну, характеристичну. При цьому надзвичайно важливим у публіцистичних текстах є використання різних стилістичних прийомів. 3 їхньою допомогою більшість англізмів, які не $є$ новими, набувають нового звучання, адже кожен автор намагається внести в тексти публіцистичного стилю свою частку суб'єктивності, дати власну оцінку описуваним подіям, явищам, створюючи контексти, які є індивідуальними, відмінними від інших. У зв'язку з цим англійські запозичення набувають характерної новизни.

Одним із найважливіших стилістичних прийомів $\epsilon$ іронія, що досягається передусім через використання англізмів у тій сфері, якій вони не властиві (наприклад, англізми семантичної групи «Культура» в текстах спортивного характеру, економічні англізми - у політичних текстах), що увиразнює висловлювання, допомагає автору точно передати своє ставлення, настрої та переживання: 1. Веселими видалися матчі четвертого туру національного чемпіонату. Щоправда, иікавої гри власне y футбол було не так багато, але ж скільки емоцій, пристрастей $i$ образів!... До «хітів» туру можна віднести також наставника єдиної команди вищої ліги, яка ще не здобула на старті чемпіонату жодного очка (Україна молода, № 153, 22.08.06); 2. Отримавши таку «підтримку» від Януковича $i$ його «команди», БЮТівиі «за бартером» мусили «віддячити» своїм новим-старим партнерам - $i$ дали «необхідну кількість» голосів за відставку найінтелітентнішого і найпослідовнішого украӥнського міністра в нинішньому уряді (Народне слово, 5.03.09).

Англізм хim не $є$ новим, однак у такому контексті він виражає індивідуальне, суб'єктивне, властиве лише цьому автору бачення подій, що надає свіжості англізму. Пряме значення запозичення хіm - популярна пісня, мелодія; переносне - про що-небудь, що користується успіхом, популярністю, попитом [1, с. 591]. У поданому прикладі англізму із позитивним денотативним значенням за допомогою прийому іронії автор 
надає протилежного значення, бо виражає своє негативне ставлення до описуваної особи. У другому прикладі економічний термін бартер набуває стилістичного забарвлення, утрачає ознаки терміна й тлумачиться не як обмін товарами. У поєднанні 3 прийменником за цей англізм утворює яскраво забарвлений вираз, що виражає іронію. У такому контексті вираз «за бартером», імовірно, можна витлумачити як за дружньою солідарністю або взамін.

Іншим стилістичним прийомом, який теж $є$ досить поширеним та виразним у текстах публіцистичного стилю, можна назвати метафору. За визначенням А. Худолій, метафора є показником динаміки мовних змін у сучасних публіцистичних текстах, оскільки саме вона утворює ту базову схему, за допомогою якої відбувається концептуалізація досвіду і пізнання навколишнього світу [9, с. 7]. Наприклад: ...депутатам не варто було сподіватися на якісь поступки чи істотні поблажки: вони прекрасно знають, щуо в ичй боротьбі перемагає той, хто сильніший $і$ диктує свої умови переможеним. Ще б пак, адже вони самі активно брали участь у виробленні законів украӥнських «політичних джунглів». А один з основних принцииів циих джуналів - «Горе переможеним» - щуе ніхто не скасовував (День, № 126, 18.07.00). Англізм джунглі тлумачиться як густі, важкопрохідні тропічні і субтропічні вічнозелені ліси, де рослини ростуть у кілька ярусів, укриті епіфітами, перевиті ліанами [5, с. 530]. Такі ознаки, як заплутаність, недоступність переносяться на політичний грунт, виражаючи недовірливу та насторожену авторську позицію. Однак, незважаючи на достатню кількість аргументів, що підтверджують необхідність залучення англійської лексики в тексти публіцистичного стилю, існує велика кількість англійських запозичень, так би мовити, зайвих, уживання яких створює перешкоди в розумінні текстів.

Причини недоречного вживання таких англізмів різні: використання англійської лексики в тій сфері, якій вони не властиві; неправильне розуміння семантики англізмів; наполегливе залучення в публіцистичні тексти тих англомовних запозичень, що мають питомі відповідники або раніше запозичені лексеми; додавання до англійських коренів тих питомих афіксів, які стають причиною переходу цих слів до розряду стилістично зниженої лексики. Наприклад: 1. Дуже хотілося б «Регіонам» мати свого віче-прем'єра з аграрних питань (y тандемі із “Солідарністю» вони готові клопотатися за нинішнього сільгоспміністра Івана Кириленка)... (Дзеркало тижня, № 20, 01.06.01); 2. Британською топ-моделлю Кейт Мосс справді можна захоплюватися: колишні бойфренди (як Серж Піцчиорно) називають ї̈ божевільтною... (Україна молода, № 174, 22.09.06); бойфренди (як Серж Пічуцорно) називають ї̈ божевільтною... (Україна молода, № 174, 22.09.06); 3. I викрадення дітей тепер не щзо інше, як кіднепінг. А суспільство наше переймає все изе з неймовірною швидкістю (День, № 120, 08.07.05). У першому прикладі фіксуємо англізм 
тандем, що має кілька прямих значеннь: 1) послідовне розташування однакових машин або їхніх частин в агрегаті на одній геометричній осі, лінії; 2) велосипед із двома ведучими механізмами й двома сідлами, розташованими одне за одним [1, с. 524]. Унаслідок перенесення, поданий англізм почав уживатися в текстах різної тематики, переважно політичної. У переносному значенні англізм тандем тлумачиться як: 1) пара, дует; 2) єдність, союз, співдружність кого-, чого-небудь [1, с. 524]. У цьому разі доречніше, очевидно, використовувати український відповідник $\epsilon \partial н і c m b . \mathrm{У}$ другому прикладі англізм бойфренд, хоч і вживається в тексті, у якому описується британська особа, на наш погляд, $\epsilon$ недоречним, бо він здебільшого використовується в розмовному мовленні й має значення друг, товариш дівчини; чоловік, з яким зустрічається жінка зазвичай без наміру створити сім'ю [4, с. 114]. У такому контексті прийнятнішою $є$ лексема чоловік.

Третє речення репрезентує вживання англійського неологізму кіднепінг, що в українській мові був неправильно інтерпретований. Серед мовців поширилася хибна дука про те, що він тлумачиться як викрадення переважно дітей (людей) задля одержання грошей, насильницького виконання якихось вимог [1, с. 287]. Як відомо, він складається 3 двох лексем: kid та napping, де kid, дійсно, перекладається як малюк, дитина, а napping - дрімання [6, с. 212]. Згідно з іншою позицією, англізм кіднепінг походить від кidнеn (kidnap) - 1) викрадення; 2) злочин, який полягає у викраденні кого-небудь заради викупу [6, с. 922]. Отже, правомірно розуміти це англійське запозичення не лише як викрадення дітей, а й людей узагалі. Хоч, як нам здається, воно є зайвим в українській мові, адже має питомий відповідник.

Надання переваги англізмам у публіцистичних текстах свідчить про намагання їх авторів слідувати мовній моді: ...щуб не було на вулицях заторів, треба будувати підземні паркінги... (День, № 48, 15.03.08). Незважаючи на те, що англізм паркінг у мові-донорі визначають як розміщення транспортного засобу у відповідному місці на певний проміжок часу [6, с. 1258], цілком правомірно було б замість нього вживати питому лексему стоянка, що означає місце стоянки автотранспорту [5, с. 329] або постійну автостоянку [4, с. 519]. На наш погляд, необхідно паралельно використовувати ці два звукові комплекси як синоніми задля уникнення постійних повторень.

На основі всього сказаного вище можна зробити висновок про те, що в текстах публіцистичного стилю досить яскраво виражений позитивний та негативний потенціал англомовної лексики. Необхідність використання англізмів полягає в тому, що вони є засобом номінації нових понять, служать для заміни питомих зворотів короткими інтернаціональними назвами, а також мають великий стилістичний ефект, який досягається різними стилістичними прийомами (іронією, метафорою, контрастом 
тощо). Негативний уплив англізмів виявляється в недоречному їх використанні, спричиненому неправильним розумінням семантики англізмів; наполегливим залученням у публіцистичні тексти тих англомовних запозичень, які мають питомі відповідники або раніше запозичені лексеми.

\section{Література}

1. Бабик С. П. Словник іншомовних слів: тлумачення, словотворення та слововживання / С. П. Бабик , Г. М. Сюта; ред. С. Я. Срмоленко. - Харків : Фоліо, 2006. -623 c.

2. Дружин Г. В. Сучасні лексичні запозичення: прагматика, семантика, соціолінгвістика : автореф. дис. на здобуття наук. ступ. канд. філолог. наук : спец. 10.02.02 «Російська мова» / Г. В. Дружин. - Дніпропетровськ, 2006. - 19 с.

3. Українська мова : [енциклопедія]. - [2-е вид.]. - К. : Українська енциклопедія ім. М. П. Бажана, 2006. -820 с.

4. Мацько Л. І. Стилістика української мови / Л. І. Мацько, О.М.Сидоренко, О. М. Мацько. - К. : Вища школа, 2003. - 462 с.

5. Сучасний словник іншомовних слів : Близько 20 тис. слів і словосполучень / [уклад. О. І. Скопненко, Т. В. Цимбалюк]. - К. : Довіра, 2006. - 789 с. (Словники України).

6. Сучасний словник іншомовних слів / [авт.-уклад. О. П.Семотюк]. - Харків : Ранок, 2007. -464 c.

7. The new Oxford American dictionary. -2 nd ed. p. cm. by Erin McKean. 1. English language - United States - Dictionaries. 2. Americanisms - Dictionaries. PE 1628. N429 2005. - $2051 \mathrm{p}$.

8. Феллер М. Д. Стиль и знак : Стиль как способ изображения действительности / М. Д. Феллер. - Львов : Вища школа, 1984. - 168 с.

9. Худолій А. О. Динаміка функціональних змін у мові американської публіцистики кінця XX - початку XXI ст. : автореф. дис. на здобуття наук. ступеня канд. філол. наук : спец. 10.02 .04 «Германські мови» / А. О. Худолій. - K., 2004. -23 c. 